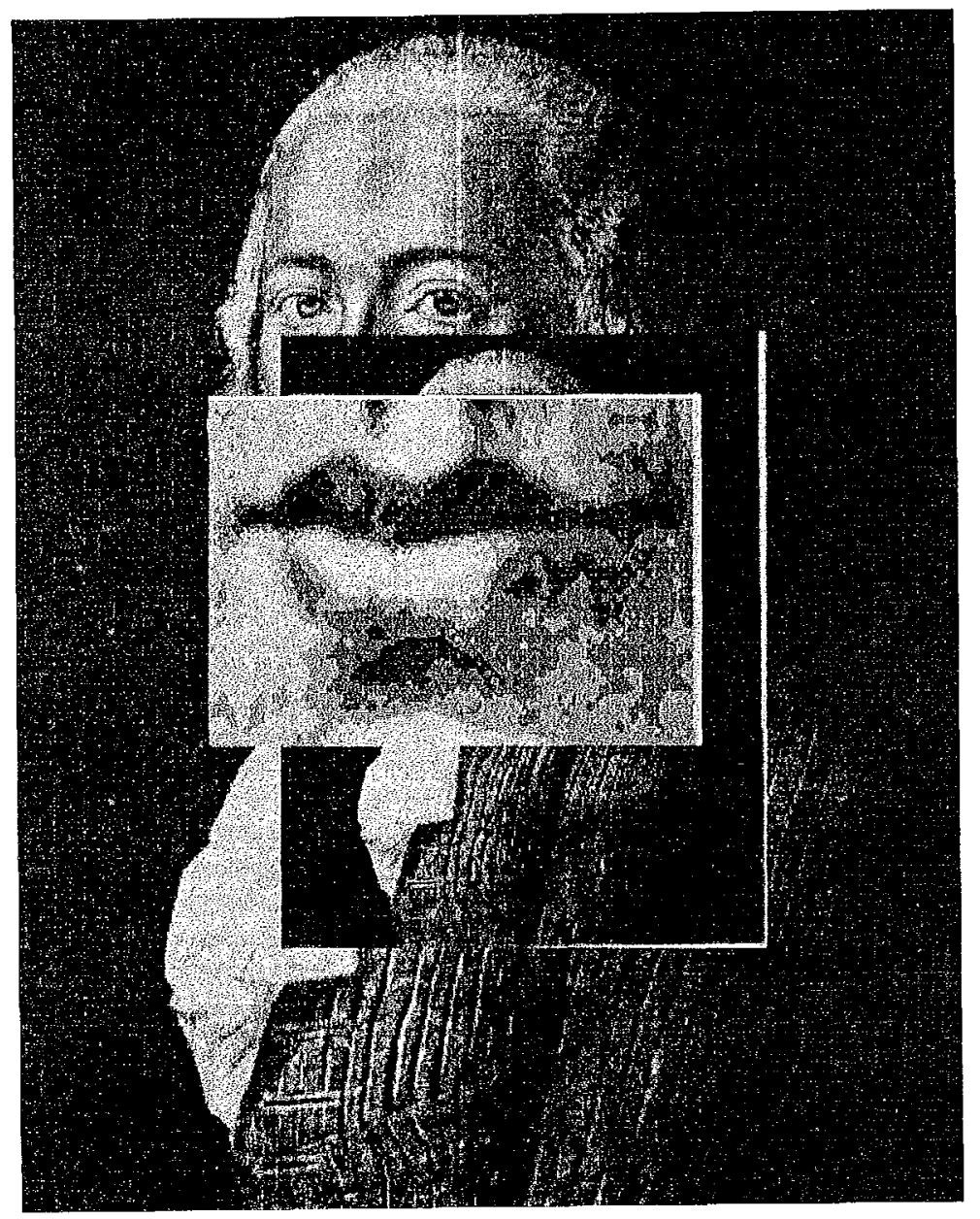

\title{
Metriske meditationer
}

\section{Per Aage Brandt}

han gik hen til sin skrivepult... og skrev, idet han skanderede versene med venstre hainds fingre mod pulten og efter fardiggorelsen af hver del udstødte et tydeligt $\mathrm{Hm}$ af tilfredshed, ledsaget af en bekraftende nikken med hovedet J. G. Fischer om Hölderlin i april 1843, cit. Jakobson, Lübbe-Grothues

Hvorfor oversætter en digter en anden digter? At oversætte er i det hele taget at åbne sin sproglige krop for en anden, der vil sætte sine varige spor i den, spor eller ar, som den oversættende har grunde til at ville 'have' $\mathrm{i}$ sig; derfor oversætter en digter ikke hvad eller hvem som helst - ligesom en musiker ikke spiller hvad som helst - , en kunstner passer på sit instrument, sit øre, sit øje, og reagerer ofte på værker, som ikke findes gode, med voldsomt fysisk ubehag. Oversætteren, der gendigter, viser i sit arbejde, hvordan en anden arbejder 'i ham', og hvad der således binder ham til en anden på en så væsentlig måde, at dette bånd viser vej til ham selv. Ligesom der ikke er to ensklingende digtere, er der derfor heller ikke to ensklingende gendigtninger; en læser må følge sin følsomhed og sin tilbøjelighed, hvilket vel at mærke ikke nødvendigvis er det samme: en gendigtning kan, selv om den kradser i læserens egne dybest banede læsevaner, blotte egenskaber i en fremmedsproglig tekst, som en anden gendigtning, der er ude i et andet ærinde, ikke blotter. ${ }^{1}$

Jeg har selv på den ene side længe været poetisk fanget, slået, forbløffet, også lidt mystificeret af Friedrich Hölderlins skrivemåde eller høremåde, ikke hans berømte og en kende overgramsede tematik, men noget særligt, der vrider stoffet, så at det næsten hvor som helst i værket afgiver en for mig uimodståelig klang. Et rytmisk fænomen. Jenaro Talens havde oversat ham til spansk ${ }^{2}$, og det virkede ikke. Thorkild Bjørnvigs version $^{3}$ forekom mig at dække ham med guldalderløv, så det for mig at høre skærende, infantile, som Goethe og de andre af samtidens kanoner formentlig især blev frastødt af, forsvandt, sammen med et eller andet $\mathrm{i}$ rytmen og versets 'kast', jeg selv mente at genkende, alt andet lige, fra... Adolf Wölfli (futzi futzi futzi...), såmænd, især fra dennes musik. Nysgerrigheden fik mig til - egentlig blot for at læse det $i$ bedste fald rimeligt klingende resultat ved en bestemt festlig anledning blandt venner - at oversætte elegien Brød og vin, som tidsskriftet Almen Semiotik derefter for sjov bragte (i nr. 14, 1987). Og på den anden side har jeg egentlig længe haft lyst til at ytre mig om poetisk metrik og rytmik, et emne, der alment 
interesserer alle poeter og poetikere, men alligevel bliver famlende behandlet i faglitteraturen. ${ }^{4}$ Eftersom Bjørnvig har ladet sig provokere af dette mit beskedne bidrag til den tyske digters yderligere udbredelse og aflytning og har ønsket at gøre rede for sit syn på de to oversættelser a det elegiske digt, hans egen (1970) og min, som tidsskriftet Passage genoptrykte i sit Hölderlin-nummer (10, 1992), benytter jeg, dog ikke uden tøven, lejligheden ${ }^{5}$ til at fremlægge nogle enkle overvejelser over de almene og dets specielle anledning.

Lad mig først kort fremstille min opfattelse af begreberne rytme og metrum. Begge har mening i musikken. Den sammenføjning af toner, vi kalder melodisk, besidder en indre kohærens, som beror dels på intervalfysikken, dels på den auditive perceptions fænomenologi, en mønsterdannelse i det hørte forløb, som forbinder akustisk erindring og forventning. Den melodiske gestaltning anvender skemaer, som er enklere end det faktisk hørte, og frembringer dermed gentagelser, således at det melodiske forløb opfattes som bestående af lokale prototyper og deres genkommende varianter. En bestemt del af denne skematik spalter sig imidlertid ud, idet perceptionsformningen udvælger en elementær egenskab ved lydlige begivenheder, nemlig selve dette, at deres ansats er mere prægnant end alt andet ${ }^{6}$, og dermed, at ansatsen som sådan - dens blotte udbrud som et 'noget' i stedet for et 'intet', 1 versus $0,-$ markerer sig selvstændigt: og da enhver tone, enkelt eller sammensat som en akkord, besidder dette træk, opstår der ved hørte toneforløb (som ved lydforløb i øvrigt) numeriske følger, hvis basale princip er, at ' 0 ' meget snart opfattes lige så prægnant som ' 1 '. I samme øjeblik som dette sker, og ' 0 ' altså også er en begivenhed, skønt negativ - en 'pause' - , har vi et metrum. En bestemt 'takt' skiller sig ud som et særlig stærkt gentagelsesmønster, der 'koder' forløbet i stærke ansatser (1) og svage ansatser (0), og som giver sig til at blande sig med de øvrige gestalter, der enten forstærker dets prægnans ved at forløbe parallelt, eller modsiger det ved ikke at gøre det; men i det sidste tilfælde sejrer takten alligevel, idet modsigelsen nu fremstår som en synkope, der blot spænder den metriske forventning yderligere op. De mange melodiske gestalter, som ligeledes forløber i tid ved siden af metrum, får altså mening som henvisning til metrum, hvilket netop er, hvad vi kalder rytme. En rytme kan 'swinge', mens metret selv ikke kan. Metret koder nu afgørende det øvrige (melodikken, harmo-nikken). Den samme melodi, hvordan den end er indrettet, kan f. eks. opfattes i tretak eller i firetakt (dog i almindelighed ikke lige let), men med helt forskellig metrisk henvisning, dvs. rytmisk værdi. Undertiden er notationen i tvivl som f. eks. i tangopartiturer, der snart skrives i to fjerdedele, snart i fire. For slet ikke at tale om $\mathrm{f}$. eks. flamencotransskriptioner. ${ }^{7}$

Dette forhold, som enhver kender, når det gælder toneforløb, men som overhovedet præger ethvert lydforløb, såsom vandhaners dryppen, viser sig, ikke uventet, at dukke op i sprogkunsten. Den sproglige 'audition' hører stavelser som elementære begivenheder, hvordan de end fungerer i ordenes og sætningernes verden, formentlig forstærket af den talendes artikulatoriske selv-perception, den 'talende krops' bombarderen sig selv med kaskader af vokaliske stemtheder, adskilt af konsonantiske rammer eller i det mindste af nye vokaliske muskelindstillinger. Også her indfinder 0-1-fænomenet sig, og ligesom det giver anledning til en tendens til prosodisk regelmæssighed i enhver længere ytring, inviterer det til metrisk rendyrkelse i den form for sprogkunst, vi kalder poesi. En poetisk metrik er altså ikke fænomenologisk bygget alene af positivt hørte stavelsesforløb $\left({ }^{\prime} 1{ }^{\prime},{ }^{\prime} 1+1+1 \ldots '\right)$, men tager form netop $\mathrm{i}$ det øjeblik, en manglende stavelse (et ' 0 '), en stavelsesmangel, om man vil, bliver hørbar. Den poetiske rytmik fremstår da i kraft af spændingen mellem de øvrige gestalter i forløbet - fonetiske, leksikalske, syntaktiske og endda semantiske - og på den anden side det rent digitale metrum. Enhver tale om 'sprogets musik' henviser til denne spænding, gjort af medløb og modløb, mellem sproglige gestalter (svarende til melodik og harmonik) og det bærende, selvstændige metrum (svarende til taktarten). Uden dette metrums selvstændighed ville det selvsagt være umuligt at opfatte hverken medløb eller modløb, og der ville ikke findes nogen sproglig rytmik.

Jeg understreger 'dialektikken' mellem metrum og rytme så energisk, fordi den endnu behandles meget ubeslutsomt af den metrikteoretiske litteratur; jeg har endda hørt et helt litteraturinstitut på given foranledning benægte dens eksistens. Spørgsmålet er lige så emotionelt påtrængende, som det er uafklaret. I praksis kender vi imidlertid forskellen mellem (musisk) metrum og (sprogligt motiveret, synkoperende) rytme fra oplæsningens tommelfingerregler: læser man poesi ved at presse metret frem gennem alt andet, får man en messende brægen, og det er ikke godt læser man derimod, som om kun den sproglige, talende intention havde form, får man en psykologisk mimren, og det er heller ikke godt. Læser man navigerende mellem disse to uheldige attraktorer, den brægende og den mimrende, bliver det bedre, men det kræver - netop - musikalitet. Der er med andre ord ingen simpel, 'god' attraktor, ingen stabilisator, man kan holde sig til, man danser på en knivsæg (der er rigtignok to grøfter at gå i, men ingen landevej mellem dem). Det er fascinerende at følge gode sprogmusikere såsom Hölderlin fra vers til vers. Man kan nemt gøre deres egne metronomiske fingerøvelser efter, selv om man kun har deres skrevne tekst at holde sig til.

Jeg kan dernæst ikke lade være med at nævne den markante forskel mellem, hvad jeg vil kalde to dominerende traditioner i den vestlige høremåde, når det gælder vers, nemlig en latinsk metrik (LM) og en germansk metrik (GM). De lever begge i bedste velgående, skønt vort århundredes frie vers har trængt opmærksomheden om dem i baggrunden. Jeg har ikke fundet sagen beskrevet noget sted, men jeg mener at møde den hver dag som læser, oplæser, tilhører og oversætter.

Et som one-liner brugbart vers af Boileau (Epitres, III, 48) kan illustrere sagen 


\section{Le moment où je parle est déjà loin de mo}

Det er en ualmindeligt regelmæssig aleksandriner ${ }^{8}$. (uu- uu- / uu- uu-) Hos Baudelaire som hos andre post-klassiske digtere finder vi i et og samme digt både hyperregulære medløbere som:

Citadin, campagnard, vagabond, sédentaire,

og modløbende størrelser som:

En haut, le Ciel! ce mur de caveau qui l'étouffe,

naturligvis med en vis dramatisk effekt, der følger af forskellen mellem sådanne to fraseringer. ${ }^{9}$ Det interessante er imidlertid forholdet mellem metrets numeriske elementer og sprogets stavelsesinvestering i dem, et forhold som adskiller LM og GM.

En stavelse er imidlertid både en metrisk enhed og en sproglig enhed. Hvis vi ved kvantitet her kun forstår trykværdien - ikke stavelseslængden, som jo i antikken komplicerede sagerne væsentligt - kan vi sige, at det er stavelsesrækken, den metriske og den sproglige kvantitet mødes, når en rytme tager form. Denne rytmiske form kan kaldes en konstitutiv konflikt. Og den påfører os desværre en terminologisk konflikt: skal vi tale om stavelsesrækkens metriske og sproglige trykstruktur hver for sig, må vi omgås de gængse betegnelser, der nemlig ikke gør det, med forsigtighed. Jeg vil bede den tænksomme læser tænke det foregående og det følgende igennem med ubønhørlig og kritisk grundighed (Ralentir, travaux! - som Breton siger ${ }^{10}$ ).

Enhver kan se, at leksikalsk tryk og syntaktisk tryk ikke behøver a falde sammen med metrisk tryk; et metrisk stærktryk (1, en stavelse opfattet som ' '-') rammer ofte et sprogligt svagtryk (En-haut-le-...) og udvisker et sprogligt stærktryk (...le-Ciel-ce-mur..., Ciel nedtones metrisk). Det er det, jeg kalder modløb. Hvis vi siger, at verset metrisk består af en række numeriske figurer (f. eks. 001, manifesteret i medløb af aleksandrineren dominerende sprogtrykfølge anapæsten: uu- , (Ci-ta-din)), og at disse figurer danner en konfiguration svarende til et eller flere vers (fire figurer aleksandrineren, hvis konfiguration således er et tetrameter, 001 001, 001 001), er metrikken altså globalt set organiseret på to niveauer: figurerne og konfigurationernes. Og på begge niveauer rejser problemet sig naturligvis om den sproglige kvantificering, der følger af stavelsesinvesteringen.

Jeg tror, man kan formulere den afgørende regelforskel på følgende måde: i LM gælder det, at 1) stavelsesinvesteringen skal svare numerisk til konfigurationens figurindhold, dvs. stavelsesantallet ligger fast - bortset fra cæsuren og versets 'udlyd', der kan have en åben, ikke tællende stavelse;
2) eftersom stavelsesantallet er fast, kan de metriske figurer høres, selv om sprogtrykfølgerne ikke svarer til de metriske figurers trykfølger, og konfigurationens række af metriske stærktryk bliver uafhængig af dens række af sproglige stærktryk (Baudelaires vers: En haut... har fem sproglige, men fire metriske stærktryk)

I GM gælder det derimod, at 1) det er stavelsesinvesteringen, der er uafhængig af figurindholdet, dvs. stavelsesantallet ligger ikke fast, hvorfor 2) de metriske figurer ikke kan høres, medmindre sprogtrykfølgerne faktisk i hovedtræk svarer til de metriske figurers trykfølger, hvilket medfører, at konfigurationens folge af metriske stærktryk bliver numerisk afhængig af dens følge af sproglige stærktryk. Man kan altså her på konfigurationens niveau afgøre, hvilket 'meter' der er tale om, idet man blot behøver at tælle dens følge af sproglige stærktryk; hvilket man som sagt ikke kan i LM.

Kong Kristjan stod ved højen mast og holdt sig fast

ville derfor være en antagelig moderne fransk aleksandriner (efter LM):

*Kong-Krist-jan-stod-ved-høj-en-mast-og-holdt-sig-fast

Cæsuren er lovlig dristig. Men i danske øren er verset nødvendigvis jambisk (efter GM):

Kong-Krist-ian-stod-ved-hø-jen-mast-og-holdt-sig-fast

Den jambiske læsning trækker rigtignok stærktryk frem, hvor sprogtrykket ikke har dem, f. eks. sprogtrykket holdt-sig-fast, der metrisk bliver til holdt-sig-fast. For kontrastens skyld kan man jo forsøge en trokæisk læsning:

${ }^{*}$ Kong-Krist-ian-stod-ved-hø-jen-mast-og-holdt-sig-fast

Dette monstrum vil med bestemthed blive afvist af 'intuitionen', som hermed bekræfter den regel, jeg har foreslået.

Denne regel gælder imidlertid også for Hölderlins poesi, og derfor kan man ikke lade, som om hans disticha og deres heksameterpentameterfølge er 'daktyliske' i klassisk LM-forstand. Vi er, hos Hölderlin, i et GM-univers. Det nytter intet at påstå, at Brot und Wein ${ }^{11}$ i heksametret siger: -uu -uu -/-uu -uu - , daktylos-daktylos-bum; daktylosdaktylos-bum (på den latinske manér), når allerede det første distichon lyder:

Rings um ruhet die Stadt; still wird die erleuchtete Gasse Und, mit Fackeln geschmückt, rauschen die Wagen hinweg. 
Vi kan simpelthen ikke bruge bumbummelum-analysen. Dens resultater er meget forkerte:

*Rings-um-ruh-et-die-Stadt;-still..

Sådan kan man ikke gøre. Sådan gør digtet i hvert fald ikke. Cæsuren falder ved semikolon i første vers og ved et komma i andet vers. Der skal være tre metriske stærktryk før cæsuren i første vers og tre efter den; to før cæsuren $\mathrm{i}$ andet og tre efter den. Disse tryk skal hentes blandt de sproglige 'kandidater' til denne metriske værdighed. Man er nødt til at lytte til sproget for at finde en god løsning. Jeg foreslår:

Rings-um-ruh-et-die-Stadt;still-wird-die-er-leuch-te-te-Gas-se,

Und-mit-Fa-ckeln-ge-schmückt,rau-schen-die-Wa-gen-hin-weg.

Hvorfor ikke still-wird? Det ville være sprogligere, det inverterede prædikat ville bevare sit naturlige syntaktiske stærktryk: wird-still. Men metrisk giver denne mulige løsning en uheldigt klingende række: stillwird-die-er-..., som ved siden af ruh-et-die... og leuch-te-te... samler for mange svagtryk; tendensen er daktylisk: -uu..., og -uuu... er mindre heldigt, hvis konteksten er fri for ...uuu... Og det er tilfældet i denne poesi. Medmindre vi har en synerese: still-wird-die^er... Figuren 1-0-0 gengive således ikke nødvendigvis af digtets stavelsesinvestering; vi har Ringsum... og Und-mit-... ; det afgørende for dette tillempede, germaniserede elegiske versemål i GM er konfigurationens trykrække:

heksam. $\quad \ldots 1 \ldots 1 \ldots 1(\ldots) /(\ldots) 1 \ldots 1 \ldots 10$

pentam. $\quad \ldots 1 \ldots 1(\ldots) /(\ldots) 1 \ldots 1 \ldots 1$

hvor svagtryksleddene '...' kan bestå af én eller to stavelser; (...), som kun optræder omkring cæsuren, kan dog også bestå af nul stavelser. Men langtfra nødvendigvis. Heksametret ender ('kvindeligt') på 0 og pentametret ('maskulint') på 1. Tre på hinanden følgende svagtryk, som er maksimum, forekommer således undertiden ved cæsuren (strofe 2,2):

Weiss, von wannen und was einem geschiehet von ihr

Weiss,-von-wan-nen / und-was-ei-nem-ge-schieh-et-von-ih

Man kunne oversætte denne metriske konfiguration til den gængse notation i en løsere form, idet parenteser nu betyder fakultativitet, og det tilføjes, - eftersom formlen ikke selv kan sige det - , at det kun i versets begyndelse og ved cæsuren er tilladt at udelade begge svagtryk, og at fire på hinanden følgende svagtryk er udelukket:

\section{heksam. $\quad(u)(u)-(u)(u)-(u)(u)-(u)(u) /(u)(u)-(u)(u)-(u)(u)-u$}

pentam. $\quad(\mathrm{u})(\mathrm{u})-(\mathrm{u})(\mathrm{u})-(\mathrm{u})(\mathrm{u}) /(\mathrm{u})(\mathrm{u})-(\mathrm{u})(\mathrm{u})-(\mathrm{u})(\mathrm{u})-$

Metriske stærktryk må ikke realiseres af lutter sproglige svagtryk.
Metriske svagtryk må ikke realiseres af lutter sproglige stærktryk. Men overensstemmelsen behøver i øvrigt ikke at være mekanisk - hvilket den strengt taget heller ikke kan være, idet sproglige trykforskelle ikke kan reduceres til kun to værdier. Der er kort sagt tale om et dominerende medløb i en sådan metrik (GM). Den kontrollerede omtrentlighed giver anledning til en melodisk frasering, som ikke 'spænder' nær så hårdt som i det, jeg har kaldt den latinske metrik (LM). Man kan sige, at metrum og sprogtryk i GM er tættere på hinanden i konfigurationen, mens de ti gengæld i LM er tættere på hinanden i figuren, hvor de ligefrem kan skurre vildt mod hinanden, hvad de aldrig kan i GM - heraf hvad man kan opleve som LMs hårdhed og GMs ømhed. Hvordan går det da, når der oversættes tværs over LM/GM-grænsen? Dette spørgsmål burde tages op i lyset af de metriske forhold, for så vidt disse ikke rokkes af, men selv betinger, oversættelserne; og den nævnte grænse er, såvidt jeg kan se, indtil videre urokket.

Lad os nu, således udrustet, i det mindste studere elegiens første strofe; jeg udhæver min læsnings metriske stærktryk:

Rings um ruhet die Stadt; / still wird die erleuchtete Gasse,

Und, mit Fackeln geschmückt, / rauschen die Wagen hinweg.

Satt gehn heim von Freuden / des Tags zu ruhen die Menschen,

Und Gewinn und Verlust / wäget ein sinniges Haupt

Wohlzufrieden zu Haus; / leer steht von Trauben und Blumen,

Und von Werken der Hand / ruht der geschäftige Markt.

Aber das Saitenspiel tönt / fern aus Gärten; vielleicht, dass

Dort ein Liebendes spielt / oder ein einsamer Mann

Ferner Freunde gedenkt / und der Jugendzeit; und die Brunnen

Immerquillend und frisch / rauschen an duftendem Beet.

Still in dämmriger Luft / ertönen gelaütete Glocken,

Und der Stunden gedenk / rufet ein Wächter die Zahl.

Jetzt auch kommet ein Wehn / und regt die Gipfel des Hains auf,

Sieh! und das Schattenbild / unserer Erde, der Mond,

Kommet geheim nun auch; / die Schwärmerische, die Nacht kommt,

Voll mit Sternen und wohl / wenig bekümmert um uns,

Glänzt die Erstaunende dort, / die Fremlingin unter den Menschen,

Über Gebirgeshöhn / traurig und prächtig herauf.

Såvidt jeg kan se, følger strofens ni disticha den angivne formel nøje. Der er imidlertid kun to rent daktyliske vers, Sieh!... og kadencen Über.. Heksametrets udlydende svagtryk og pentametrets udlydende stærktryk står vidunderligt frem. Ord med to metriske stærktryk spiles ejendommeligt ud (Jugendzeit, Schwärmerische) og nedsætter versets 'hastighed'.

Bjørnvigs stofe klinger imidlertid således:

Rundtom hviler min by; / tavs ligger den oplyste gade, 
og, med faklerne tændt, / bruser nu vognene bort.

Mætte af dagens glæder / går folk til ro, og et tænksomt

NB hovede vejer tilfreds / dagens gevinst og tab

op mod hinanden derhjemme; / tomt står for druer og blomster

og fra hændernes værk / hviler det travle torv.

Men fra haverne toner / et strengespil fjærnt; måske en

NB elskende spiller dér / Eller en ensom mand

husker på fjæme venner / og ungdomstiden; bestandig-

NB vældende bruser hver brønd / frisk ved det duftende bed.

Dæmpet i dæmringsluft / bredes lyden fra svingende klokker

NB og, kommet timen i hu, / råber en vægter dens tal.

Nu kommer også en luftning, / bevæger de øverste kroner

henne i lunden; / vor Jords skyggebillede, se!

månen kommer nu også; / den sværmeriske, natten

NB kommer, af stjerner fyldt, / lidt kun bekymret om os,

går den forbavsendes lysglans, / hun, iblandt mennesker fremmed,

NB op over bjergenes ryg / sorgfuldt og prægtigt frem.

De seks med NB angivne vers er ikke pentametre, men heksametre ${ }^{12}$; det ville koste frygtelige tungevridninger at fjerne de overskydende stærktryk. (F. eks.: vældende-bruser-hver-brønd... - læg-ti-læs-kul-i-torum, som vi siger for at gøre nar ad LM) ${ }^{13}$. I Kadencen skulle enten op eller selve ryg fjernes, medmindre man vil have: op-over-bjergenes-ryg...).

Derimod er udlydene gengivet.

Hvad jeg selv foreslog, var følgende:

Rundtom hviler sig byen; / tavs blir den oplyste gade

Og smykket med fakler / bruser vognene bort.

Mætte af dagens glæder / går menn(e)skene hjem for at hvile,

Og tab og gevinst / vejer et tankefuld thoved

Veltilfreds i sit hjem; / tomt står for druer og blomster

Og hviler fra håndens / værker det driftige marked.

Men en strengeleg lyder / fjernt fra haver; måske dér

En elskende spiller / eller en ensom mand

Fjeme venner erindrer / og ungdomstiden; og kilderne,

Stedsespringend(e) og friske, / risler ved duftende bed.

Stille i skumrende luft / toner bevægede klokker,

Og erindrende timen / råber en vægter dens tal.

Nu kommer også en vind / og oppisker lundens kroner,

Se! og vor jords / skyggebillede, månen,

Kommer lønligt nu også; / den sværmende, natten, kommer,

Fuld af stjerner / og vel lidet bekymret om os,

Stråler hun dér, den forbløffende,/denne blandt mennesker fremmede,

Over bjergenes højder / bedrøvet og prægtig frem.
Metret er nu trykrigtigt. Teksten er samtidig lagt lige i hælene på Hölderlin, uden unødvendige omskrivninger, og søgt giort ret ordret, så at flest mulige af hans egne ord rammes af de samme tryk $i$ deres oversættelse. Det gælder de to klart infantile åbninger: Aber-dasSaitenspiel... og Jetzt-auch-kommet... Til gengæld er udlydenes vekslen mellem stærk- og svagtryk ikke gengivet systematisk, prisen er ganske enkelt for $h ø j^{14}$, hvis de danske vers skal kunne komme i nærheden af de tyskes 'kast'. Og denne bestræbelse er afgørende i min tilgang.

Hvis pladsen tillod det, ville det være spændende ${ }^{15}$ - men også tålmodighedskrævende - at gennemgå hele digtet på denne måde, med fingeren mod bordkanten. Jeg ser imidlertid, at den allerede ikke mere tillader noget som helst; jeg kan kun lige nå at tilføje, at alt det øvrige, syntaksen og ordvalget, ja endog og endda især semantikken, står i et aktivt forhold til disse rytmiske hensyn. I begyndelsen var...ruach, den skabende, vuggende bevægelse.

Noter:

1. Jeg tænker in casu på T. Brostrøm, "Kun til tider tåler vi gudelig lykke", Information, 1. juni 1992, p. 12: "Dog har Per Aage Brandt nyoversat digtet "Brød og Vin" med enkelte forbedringer, men til gengæld spoleret det smukke elegiske metrum, som Bjørnvig mestrer." Sådanne bemærkninger inspirerer til overvejelser over det elegiske metrums skønhed og faktiske formelle egenskaber. Man må gå ud fra, at det for at kunne være smukt også må eksistere.

2. Friedrich Hölderlin, Las grandes elegias (1800-1801), poesía Hiperión, 1980.

3. Friedrich Hölderlin, Brød og vin og andre digte, Brøndum 1970, med grafik af Søren Hjorth Nielsen.

4. Selv Henri Morier, hvis Dictionnaire de Poétique et de Rhétorique, PUF 1989 (4. udg.), der ellers med sine 1320 ss. har plads til lidt af hvert, anvender kun $\mathrm{i}$ alt 7 ss. (mètre, pied métrique) på metrikken: her opregnes kun grundfigurerne i latinsk verselære.

5. Udfordringen er ærefuld, men ikke ideel til formålet; det er nærmest videnskabeligt bevist, at den polemiske genre udelukker udøvelse af erkendende fornuft. Det lykkes heller ikke Bjørnvig at etablere et modbevis. Hans bemærkninger om "omvendt" ordstilling, som ikke optræder hos de store digtere, er hvad jeg slet og ret må kalde galimatias. (Gut auch sind und geschickt einem zu etwas wir... en typisk Hölderlin-linie, Blödigkeit).

6. En interessant forskel mellem visuelle og auditive begivenheder er, at de første "bliver stående" lige så længe, som kilden er aktiv, mens de sidste - i lighed med især taktile indtryk - "fader ud" efter ansatsen, selv om kilden orbliver aktiv. Denne for lige udtryk overhovedet: forskellen mellem billeder og alt andet beror herpå. Se f. eks. Ray Mitchells seguiriya-transskription gengivet i Jørgen Laurvig Flamenco - ndir engle og dæmoner elsker, Hovedland, 1986.

7. En metrisk direkte oversættelse kunne simpelthen lyde: "talens øjeblik er 
allerede forbi". Dvs. ta-lens-ø-je-blik-er-al-le-re-de-for-bi. Den har dog måttet sige farvel til je og moi. Men denne oversættelse følger LM, ikke Gm, og vil derfor være usandsynlig.

8. Digtet Le couvercle, Nouvelles Fleurs du Mal, XVI

9. Kør langsomt, vejarbejde! Cf. Banana Split, nr. 2, 1992, ss. 53-54.

10. Jeg citerer her fra Jochen Schmidts Hölderlin. Gedichte, Insel Taschenbuch,

11. 1984.

12. Det sjette heksameter - Still in dämmriger... - er særlig lydfølsomt, fordi dets emne er disse tonende klokker; Hölderlins seks vokaler er alle forskellige; Bjørnvigs påsmurte lydmaleri - Dæmpet i dæm... - er et overgreb, der må undre.

13. Tre lignende tungevridninger, som forekommer i Bjørnvigs tekst, virke påfaldende uhölderlinske: tavs ligger...; bredes lyden...; skyggebillede... Orddelingen: bestandig $/$ veld noget sted foreta noget sted foretager sig. En ekspressionistisk figur, der vel ikke er grund til at indføre.

14. Min fornemmelse er, at Bjørnvig har stolet for meget på netop denne effekt, som da har kostet ham den for store afstand til digtet på de centrale rytmiske områder og de deraf følgende udflugter og omskrivninger.

15. Jeg glæder mig i det hele taget til at høre, hvad ein sinniges Haupt ved at veje Gewinn und Verlust vil sige til disse metriske overvejelser. Jeg gor mig klart, Gewinn und Verhst vil sige til disse metriskeovervejelser. Jeg gor mig klart, at de ikke er "god latin", og venter mig lærige vulkanudbrud. Desværr bygger polemik helst på det i forvejen indlysende, mens vi her må etablere stridens kerne teoretisk. 